Portland State University

PDXScholar

$5-21-2020$

\title{
Investigating the Mental Health and Well-Being Effects of Neo-Pagan Spiritual Practice
}

\section{Emma Ritter}

Portland State University

Follow this and additional works at: https://pdxscholar.library.pdx.edu/honorstheses

Part of the Other Religion Commons, and the Psychology Commons Let us know how access to this document benefits you.

\section{Recommended Citation}

Ritter, Emma, "Investigating the Mental Health and Well-Being Effects of Neo-Pagan Spiritual Practice" (2020). University Honors Theses. Paper 917.

https://doi.org/10.15760/honors.939

This Thesis is brought to you for free and open access. It has been accepted for inclusion in University Honors Theses by an authorized administrator of PDXScholar. Please contact us if we can make this document more accessible: pdxscholar@pdx.edu. 
PAGANISM AND MENTAL WELL-BEING

Investigating the Mental Health and Well-Being Effects of Neo-Pagan Spiritual Practice

by

\section{Emma Ritter}

An undergraduate honors thesis submitted in partial fulfillment of the

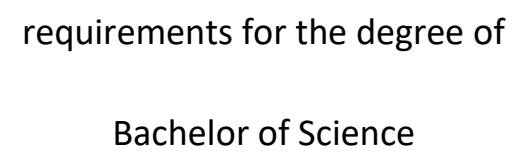

in

University Honors

and

Psychology

Thesis Adviser

Sally Eck

Portland State University 
PAGANISM AND MENTAL WELL-BEING

"The world is holy. Nature is holy. The body is holy. Sexuality is holy. The imagination is holy. Divinity is immanent in nature; it is within you as well as without."

-Margot Adler, Drawing Down the Moon, 2006

\section{Introduction}

Spirituality is hugely varied across people and has been the root for much hatred and love. The purpose of all spirituality is to be closer to whatever one believes in the divine. NeoPaganism, or a set of spiritual practices based on practices from the pre-Christian world, has gained significant traction (Adler, 2006). Studies of Pagan spirituality cover numerous topics, all imperative to understanding the lived experience of Pagan individuals. Topics range from workplace discrimination to social work with Pagan youth to the well-being effects of spiritual ritual. Pagans have a unique spiritual structure: a non-authoritarian, nature-based, egalitarian, polytheistic religion that is highly individual. This is noticeably different from the more common mono-theistic religions. Pagans often pride themselves on what makes their spirituality unique and functional in ways Christianity is not.

For this paper, I will be bringing together multiple articles to paint a picture of Pagan practitioners and the well-being effects of their spiritual practices. This work can serve as a guide for those who wish to learn more about Pagans in their lives, but also find ways to introduce aspects of Pagan practice into their lives. Three main dimensions will be discussed: connection to nature, spiritual ritual and empowerment, and rejection and discrimination. By analyzing these aspects of Pagan life, we can understand the mental health and well-being effects granted by Pagan practice.

\section{Background}


PAGANISM AND MENTAL WELL-BEING

In the book Drawing Down the Moon: Witches, Druids, Goddess-Worshippers and Other

Pagans in America, by Margot Adler ${ }^{1}$, Paganism is described as a nature-based spirituality that claims to have roots in ancient pre-Christian tradition (2006). Much of it is steeped in misconceptions and stereotypes (Harris et. al., 2016). Often people misunderstand those who follow it because they are simply unaware or miseducated. Modern Paganism is complex and varied among those who practice it. There is no holy book, no official organization that controls all Pagans, but a variety of groups and ideologies falling under one umbrella (Adler, 2006). Some pagans practice in groups, others in solitary. People also meet each other through the internet (Jenson \& Thompson, 2008). There is research analyzing and documenting the community, but how do Pagan practices affect the mental health of the practitioners of Pagan spirituality? Current research fails to answer this question.

Perhaps the most ubiquitous assertion at the beginning of books on Paganism is: "this does not represent everyone in the Pagan community" (Adler, 2006). Pagan practice is broad and varied, with spiritualities ranging from Wicca to shamanism to Hellenic polytheism to eclectic practices that take from a variety of practices (Adler, 2006). While Pagan practice is varied, there are several core practices that fall under the domain of psychological research: spiritual ritual, meditation, and connection to nature. I will bring together studies about Pagan practice specifically as well as other studies about the practices to create a better understanding of the mental well-being and health effects of Pagan and, more specifically Wiccan practice and spirituality.

\footnotetext{
${ }^{1}$ This is not a peer reviewed source; however, I have found it to be reliable. She writes about her own experience in the Pagan community in a qualitative manner. Also, it is a more ecological source, speaking to what actual Pagans read and practice from.
} 
PAGANISM AND MENTAL WELL-BEING

As it is used today, the word 'Pagan' is an umbrella term for a variety of different practices. These practices include such variances as Wicca, Druidry, and other paths that choose not to identify with a dominant monotheistic religion, such as Christianity (Adler, 2006). The foremost text on the subject, Drawing Down the Moon: Witches, Druids, Goddess-Worshippers, and other Pagans in America by Margot Adler (2006) loosely details the practices of modern Pagans. One spiritual characteristic most Pagans share is polytheism (Adler, 2006). Some practitioners choose to follow many different gods and goddesses from various cultures across history; others simply follow one God and one Goddess. Wicca, one of many practices under the Pagan umbrella, is one such duo-theistic practice (Adler, 2006).

Wicca is based on two deities: a God often depicted as a horned god, and a Goddess often depicted as a triple goddess, or the lunar representation of the three stages of life (maiden, mother, and crone) pictured below (Yardley, 2008). Another important symbol in Wicca is the pentacle, or a pentagram encircled with a circle (Yardley, 2008).
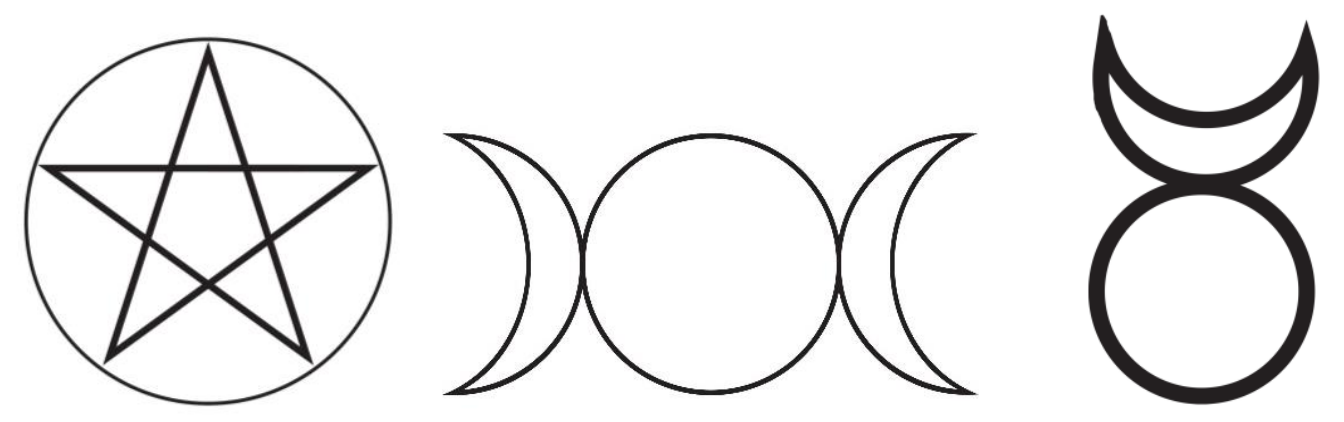

Symbols denoting the pentacle (right), the triple goddess (middle), and the horned god (left). (Ancient-Symbols.com, 2020).

Wiccans celebrate two types of holidays: sabbats and esbats (Yardley, 2008). Sabbats are based on the movements of the sun and the male God and include equinoxes and solstices 
PAGANISM AND MENTAL WELL-BEING

(Adler, 2006). These holidays include Samhain (Halloween), Imbolc, Beltane, and others (Harris et. al., 2016). These holidays are generally celebrated by celebrating the time of year they take place (Adler, 2006).

Rituals take many forms and can be done for many reasons: to celebrate holidays, celebrate life events, or to manifest favorable events (Yardley, 2008). Rituals can be larger, more formal affairs or small everyday acts, such as meditation or appreciating nature (Harris et al., 2016). These acts are often done to celebrate nature in its elemental forms (fire, air, earth, water). Rituals can be done in a group, such as a coven, or done in solitary. Many rituals are also done to honor various deities one may worship (Harris et al., 2016). Some, although not all, practice magic. Generally, magic is viewed as a universal energy that flows through the world that can be manipulated by a practitioner (Harris et al., 2016). Because ritual is such a large part of the Pagan experience, I will be investigating this practice in my final thesis.

Nature is of great importance in all Pagan spirituality. Wicca is no exception. In Adler's book (2006), she quotes an article by Lynn White published in the journal Science entitled "The Historical Roots of our Ecological Crisis", which said, "Christianity in absolute contrast to ancient Paganism...not only established dualism of man and nature but also insisted that it is God's will that man exploit nature for his proper ends...In antiquity every tree, every spring, every stream, every hill had its own genius loci, its guardian spirit...” (Adler, 2006). In contrast, Paganism emphasizes a connection and respect for nature, and a recognition of its sacredness.

Paganism and Wicca today is a very open spirituality, and anyone can become Wiccan or Pagan if they choose to do so (Adler, 2006). Being a part of a coven, or community of witches who practice together, is not required. In fact, many people are solitary practitioners and prefer to follow their own path (Adler, 2006). It depends on the individual and their preferences. Many 
PAGANISM AND MENTAL WELL-BEING

people in the religion are converts, rather than being raised Pagan, largely because it is still a young spirituality (Yardley, 2008). This is an important piece to take into consideration. This can mean the families of a Pagan practitioner can be negative concerning their spiritual practice (Yardley, 2008). Family rejection, like all rejection, can be difficult to cope with.

Many negative stereotypes of Pagan exist and are circulated among those not educated on the true nature of Pagan spirituality. For example, the 'evil Pagan,' the 'teenage goth,' 'new age hippies,' etc., are common stereotypes (Harris et. al., 2016). It should be noted that such stereotypes are largely untrue and harmful to those in the community. Pagans also feel unwelcome in places such as Alcoholics Anonymous, because of the perceived ubiquitous nature of Christianity and pervasive monotheism (Yardley, 2008). There are limited places where Pagans feel that they can be open about their spirituality, or at least have it respected. This is another aspect of Pagan experience to be considered in my final thesis project: rejection and how it influences the psychological well-being of a subject.

\section{Methodology}

To investigate my research question, I decided to conduct a literature review of available research on Neo-Pagans and Wiccans and mental health and well-being. I will break what I have collected down into factors that most notably influence Neo-Pagans and Wiccans: worship of nature, spiritual ritual, self-empowerment, and family rejection. This is useful information for therapy practitioners, teachers, and people who simply have Pagan friends or family they wish to better support or even learn from. Perhaps this will be useful work for further studies on NeoPagan spirituality. By bettering our understanding of Pagan spirituality and practice, we can better support the Pagans in our lives and better our relationships with them. 
PAGANISM AND MENTAL WELL-BEING

Worship and Veneration of the Natural World

Paganism is most notable for its emphasis on the sacredness of nature. While this is not exclusively a Pagan pursuit, this portion of spiritual practice is integral to most Pagans' lives, and many Pagans are involved in environmental activism (Adler 2006, Jensen \& Thompson, 2008). It has been noted across various studies that time spent in nature can lead to stress reduction, but what about a stronger connection to nature? Pagans feel a reverence for nature; nature is something that is divine. Pagans do not only spend time in nature, they are connected to it in a unique and spiritual way.

In the book "Mental Health and Well-being: International Contributions to the Study of Positive Mental Health" by Keyes (2013) the author cites E. O. Wilson and the hypothesis of biophilia, which states that we have hard-wired evolutionary drives to be more connected to nature. This is considered a possible explanation for why humans enjoy natural landscapes, and they cause feelings of calm and reductions of stress (Keyes, 2013). Keyes continues to note that humans have been moving towards more urbanization, and fewer and fewer people live in rural areas (Keyes, 2013). He goes on to detail numerous studies, which find numerous benefits of a strong relationship with nature. A spiritual connection with nature can reduce stress, but also cause people to seek closeness and community (Keyes, 2013). Nature connection boosts positive feelings, comforts us, and makes us more open to feelings of wonder and respect for nature (Keyes, 2013).

In work done by Cooley, Jones, Kurtz, and Robertson, they created a meta-synthesis of studies of talking therapy in outdoor settings (2020). Time spent in nature has numerous mental and psychical benefits, lower stress and decreasing the likelihood of illness (Cooley et. al., 2020). This is explained by the Bronfenbrenner ecological systems theory, wherein individuals 
PAGANISM AND MENTAL WELL-BEING

act as a part of a whole; various larger spheres of influence (Cooley et.al., 2020). Actions

conducted in the outer world are imperative to inner processes (Cooley et. al., 2020). Therapy, thus, benefit incredibly from being outside in natural settings. Both therapy practitioners and participants enjoyed the experience more when it was outside (Cooley et.al., 2020).

However, perhaps the benefits of time spent in nature can go beyond just stress reduction. In the article "Why is Nature Beneficial? The Role of Connectedness to Nature" by Mayer, Frantz, Bruehlman-Sencal, and Dolliver (2009), investigates the effect having a more spiritual relationship with nature has on an individual's mental health and well-being. The researchers conducted three different studies: the first study focused on connectedness to nature as a potential mediator in the effects of exposure to nature, the second one looks at whether simulated experiences of nature can still provide the benefits of time spent in nature, and the third was the same as the second but was better for statistical analysis (Mayer et. al., 2009). The first study found that connectedness to nature is a powerful mediator in the effects of time spent in nature and increased the beneficial effects (Mayer et. al., 2009). The second study found that time spent in real nature, rather than simulated, was more beneficial (Mayer et. al., 2009). Considering this, we can determine some important things about Neo-Paganism: time spent in nature is extremely beneficial, as is having a stronger and more spiritual connection.

\section{Spiritual Ritual and Self-Empowerment}

Ritual is a very important part of Pagan spirituality. Not all Pagans meet in a group, like a coven, some choose a solitary practice (Adler, 2006). That said, ritual is important to Pagan spirituality. Pagan health is based on models of holistic, balance and well-being (Kirner, 2014). With this focus, Paganism focuses on the individual, rather than societal pressures or rules set by 
PAGANISM AND MENTAL WELL-BEING

a holy code. This focus on individual well-being and power is extremely important to understanding how Pagans practice and perform rituals ${ }^{2}$.

Feminist spirituality is another practice that falls under the Pagan umbrella. While I have observed problems within this spirituality, such as transphobia directed at transgender women, I felt it was still worth it to include here. In the article "Women's Empowerment Through Feminist Rituals" by Diann L. Neu, (1995) the rituals of five different women are detailed and analyzed. The purpose of the rituals ranges from recovery from celebrations surrounding coming out as a lesbian, to seeking support surrounding the decision to have an abortion, to recovering from trauma. Much of the piece is focused on how women come to these groups to find a sense of community and support surrounding difficult life events, but also around the events of joy (Neu, 1995). This sense of community and support is important for these women and their healing process. These rituals are also focused not on adapting to the rules of society, but by actively pushing against them, in accordance with feminist theory (Neu, 1995). As such, the rituals are critical of the forces of sexism, agism, homophobia, and racism, and seek to reduce the impact these systems have on the lives of these women (Neu, 1995).

In a separate paper entitled "Healing Community: Pagan Cultural Models and Experiences in Seeking Well-Being” by Kirner (2014), the results of The Pagan Health Survey Project are detailed. In the analysis of responses received from participants, it was concluded that Pagans seek healing with distinct focuses: balance, holism, and the mind-body connection (Kirner, 2014). This was analyzed using a lens of cultural models, where there are common schemas called 'social facts' found in cultures that help guide those who are a part of that culture

\footnotetext{
${ }^{2}$ Please see the appendix for an example of a Pagan ritual from Drawing Down the Moon.
} 
PAGANISM AND MENTAL WELL-BEING

(Kirner, 2014). One such social fact is the idea of conversion to Paganism has a sort of homecoming, rather than the Christian concept of conversion, which focuses on salvation (Kirner, 2014). This is a striking contrast, where converting to Paganism is almost a relief, and done for the benefit of oneself, rather than the saving of one's soul. It is an accepting of who you are now, rather than believing what you are is fundamentally bad in some way. Another social fact is the focus on macrocosmic forces, such as masculine and feminine energies (Kirner, 2014). This macrocosmic view also incorporates facets of personal identities, such as masculinity and femininity. Because of this, it can be concluded that Pagans can view themselves as divine and sacred. This is an excellent worldview for self-empowerment.

Paganism also focuses on different life stages, as emphasized through the practice of croning rituals, which are detail in the article "Experiences from Pagan Womens: A Closer Look at Croning Rituals" by Manning (2012). This is a qualitative study of five women that focuses on how aging Pagan women view the process of aging (Manning, 2012). Ageism, or discrimination on the basis of age, is a significant problem in American society, and it has strong effects on the lives of ageing women (Manning, 2012). Older women are treated as invisible or are labeled with the 'old woman' stereotype (Manning 2012). The croning ritual is regarded as a celebration of aging in Pagan communities, an idea in direct opposition to ageist ideas (Manning, 2012). The themes that emerged during Manning's research included celebration through the croning ritual and gaining visibility through said ritual (Manning, 2012). There is a process of reclaiming the word crone, using it as a positive identifier rather than a derogatory term (Manning, 2012). The ceremony was a marker of the experiences the women had had over their lifetime, and a celebration of the wisdom they possess (Manning, 2012). Conducting the ritual increased their visibility as aging women, in a celebratory and empowering manner (Manning, 2012). With this 
PAGANISM AND MENTAL WELL-BEING

in mind, we can further understand how spiritual rituals like these can be beneficial for people, especially those that are disenfranchised or ignored by the larger culture. This process of reclamation and celebration of ageing has power positive mental effects.

Spiritual ritual is a powerful tool in Neo-Paganism, allowing practitioners to have a greater connection to themselves and deities. Rituals have numerous positive effects, and when put in combination with the ideology of nature as sacred, levels of well-being among NeoPagans is very high, and they have tools available to them when life becomes stressful or difficult. These benefits are quite powerful, but there are downsides to Pagan spirituality, namely the possibility of rejection and discrimination by peers.

\section{Rejection}

Rejection and discrimination come from two main sources: family and coworkers. In work by Tejeda (2015) participants stated that there was significant anxiety associated with their coworkers discovering their religious path. Participants also noted that were anxious about people finding out in their personal lives, not just their work environment. There was also significant concern surrounding the way Pagans are represented in media (Tejeda, 2015). Other commonalities among participants included microaggressions, hypervigilance, alienation, and rejection (Tejeda 2015). Workplace discrimination is dangerous because it threatens a person's ability to support themselves. Because work is where we spend most of our waking hours, it is important to fully grasp the necessity of preventing workplace discrimination. Discrimination against Pagan spirituality may not always be visible, and people are not always educated about the spiritual beliefs. This makes workplaces some of the most dangerous. 
PAGANISM AND MENTAL WELL-BEING

There are numerous places that are unwelcoming to Pagans, beyond the workplace. Some Pagans often feel unwelcome in spaces such as Alcoholics Anonymous, where there is emphasis placed on a Christian god (Yardley, 2008). Paganism is often a Goddess-centered spirituality that focuses on the sacred nature of the divine feminine (Adler, 2006; Yardley, 2008). As a result, because public resources are heavily influenced by Christian ideology, it can be difficult for Pagans to find spaces where their spirituality is celebrated and welcomed, especially with so many harmful stereotypes of Pagans being circulated.

In the case of Pagan children, there can be instances of bullying from their peers based on false ideas of their spirituality (Yardley, 2008). Some may be accosted with accusations of devil worship, yet another Christian idea. Some schools also have Christian activities that children are required to participate in, regardless of their religious identity (Yardley, 2008). This can trigger feelings of minority threat can cause anxiety among Pagan children, who may be the only Pagan in their school.

There is also the issue of minority stress. Minority stress occurs when a person is anxious because of their minority status (Kirner, 2014). Pagans are often associated with the LGBTQ community, and the process of being open about one's Pagan spirituality is often called 'coming out of the broom closet' (Adler, 2006; Kirner, 2014). This emphasis on 'coming out' illustrates the possible threat of rejection as a result being open about one's spirituality. Choosing to share one's spirituality with loved ones can be a difficult decision, one that can be distressing. This distress can impact functionality.

So, if rejection has such powerful effects, what's the point of being open about one's spirituality? In my personal experience being openly pagan, it can be empowering, and feel more authentic than hiding that part of myself away. I've had difficulties with rejection from people 
PAGANISM AND MENTAL WELL-BEING

close to me but pushing against that allowed me to become a stronger and happier person. Being open can also allow you to meet new friends who are also pagan and help build a community based on spirituality. This can help mitigate problems that arise from rejection.

\section{Conclusions}

Pagans benefit from their beliefs in several notable ways. Pagans venerate nature as sacred and holy, which can allow for increased stress reduction from time spent in nature (Adler, 2006; Mayer et. al., 2009). Spiritual ritual can allow practitioners to process difficult life events, as well as celebrate good ones (Neu, 1995). This process increases feelings of community and self-empowerment. These factors are in opposition to the discrimination and misunderstanding that Pagans face from those who do not understand Paganism or choose not to. While the rejection is difficult, there may be ways that they can be mitigated. Pagan practice is focused on well-being, healing, and empowerment, which can help mitigate feelings of otherness and stress. However, it is still imperative that those outside of Pagan communities are respectful of Pagan identity and spiritual practice. It's possible that the positives of pagan practice can outweigh the negatives, but it's also important to be supportive of the pagan community when it's needed. The need for more research on this community is great, and it is important to consider how Pagan spiritual beliefs effect those who practice it. This thesis can serve as a possible starting point for future investigations. 
PAGANISM AND MENTAL WELL-BEING

Bibliography

Adler, M. (2006). Drawing Down the Moon: Witches, Druids, Goddess-Worshippers, and other Pagans in America (3rd ed.). Penguin Books.

Cooley, Sam J., Ceri R. Jones, Arabella Kurtz, and Noelle Robertson. 2020. "'Into the Wild': A MetaSynthesis of Talking Therapy in Natural Outdoor Spaces." Clinical Psychology Review 77:101841.

Harris, Kevin A., Kate M. Panzica, and Ruth A. Crocker. 2016. "Paganism and Counseling: The Development of a Clinical Resource.” Open Theology 2(1).

Jensen, Gary F., and Ashley Thompson. 2008. "“Out of the Broom Closet': The Social Ecology of American Wicca.” Journal for the Scientific Study of Religion 47(4):753-66.

Keyes, Corey L. M., ed. 2013. Mental Well-Being. Dordrecht: Springer Netherlands.

Kirner, Kimberly D. 2014. "Healing Community: Pagan Cultural Models and Experiences in Seeking Well-Being." Pomegranate: The International Journal of Pagan Studies 16(1):80-108.

Manning, Lydia K. 2012. "Experiences from Pagan Women: A Closer Look at Croning Rituals." Journal of Aging Studies 26(1):102-8.

Mayer, F. Stephan, Cynthia McPherson Frantz, Emma Bruehlman-Senecal, and Kyffin Dolliver. 2009. "Why Is Nature Beneficial?: The Role of Connectedness to Nature." Environment and Behavior 41(5):607-43.

Neu, Diann L. 1995. “Women’s Empowerment Through Feminist Rituals.” Women \& Therapy 16(23):185-200.

Tejeda, Manuel J. 2015. "Skeletons in the Broom Closet: Exploring the Discrimination of Pagans in the Workplace.” Journal of Management, Spirituality \& Religion 12(2):88-110.

Yardley, M. 2008. "Social Work Practice with Pagans, Witches, and Wiccans: Guidelines for Practice with Children and Youths." Social Work 53(4):329-36.

All images from ancient-symbols.com 
PAGANISM AND MENTAL WELL-BEING

Appendix

The following is a ritual verbatim from the book Drawing Down the Moon: Witches, Druids, Goddess-Worshippers, and other Pagans in America by Margot Adler (2006). The ritual was written by Ed Finch.

Pagan Ritual for General Use

A circle should be marked on the floor, surrounding those who will participate in the ceremony. An altar is to be set up at the center of the circle. At the center of the altar shall be place an image of the Goddess, and an incense burner placed in front of it. Behind the image should be a wand fashioned from a willow branch. Candles should be set upon the altar...a total of five, since one is to be set at each quarter, and one will remain on the altar during the rite.

When all the people are prepared, they shall assemble within the circle. The woman acting as priestess shall direct the man who acts as priest to light the candles and incense. She shall then say:

The presence of the noble Goddess extends everywhere.

Throughout many strange, magical

And beautiful worlds.

To all places of wilderness, enchantment, and freedom.

She then places a candle at the north and pauses to look outwards, saying:

The Lady is awesome. 
PAGANISM AND MENTAL WELL-BEING

The Powers of death bow before Her.

The person closest to the east takes a candle from the altar and places it at that quarter, saying:

Our Goddess is a Lady of Joy.

The winds are Her servants.

The person closest to the south takes a candle from the altar and places it at that quarter, saying:

Our Goddess is a Goddess of Love.

At Her blessings and desire

The sun brings forth life anew.

The person closest to the west takes a candle from the altar and places it at that quarter, saying:

The seas are the domains of our Serene Lady.

The mysteries of the depths are Hers alone.

The priest now takes the wand, and starting at the north, draws it along the entire circle clockwise back to the north point, saying:

The circle is sealed, and all herein

Are totally and completely apart

From the outside world, 
PAGANISM AND MENTAL WELL-BEING

That we may glorify the Lady whom we adore.

Blessed Be!

All repeat: Blessed Be!

The priest now holds the wand out in salute towards the north for a moment and then holds it to the priestess, who also holds it out in salute. She motions to the group to repeat the following lines after her:

As above, so below...

As the universe, so the soul.

As without, so within.

Blessed and gracious one,

On this day do we consecrate to you

Our bodies,

Our minds,

And our spirits.

Blessed Be!

Now is the time for discussion and teaching. Wine and light refreshments may be served. When the meeting has ended, all will stand and silently mediate for a moment. The priestess will then take the wand and tap each candle to put it out, starting at the north and going clockwise about this circle, while saying: 
PAGANISM AND MENTAL WELL-BEING

Our rite draws to its end.

O lovely and gracious Goddess,

Be with each of us as we depart.

The circle is broken! 